\title{
Metal(loid) Bioremediation: Strategies Employed by Microbial Polymers
}

\author{
Ayansina Segun Ayangbenro ${ }^{(D)}$ and Olubukola Oluranti Babalola * \\ Food Security and Safety Niche, Faculty of Natural and Agricultural Sciences, North-West University, \\ Private Bag X2046, Mmabatho 2735, South Africa; sinasegun@gmail.com \\ * Correspondence: Olubukola.Babalola@nwu.ac.za; Tel.: +27-183-892-568
}

Received: 29 June 2018; Accepted: 24 August 2018; Published: 26 August 2018

check for updates

\begin{abstract}
Environmental pollution arising from metal(loid)s is a result of industrialization, and has led to serious health issues. Conventional methods of metal(loid) removal often results in generation of secondary waste which is toxic to the environment. Bioremediation in combination with physicochemical techniques offer an excellent and effective means of removal. The use of secondary metabolites and extracellular polymers produced by microorganisms is an effective procedure employed in metal(loid) sequestration and reduction in toxicity of contaminated environments. These biopolymers have different chemical structures and have shown varied selectivity to different metal(loid)s. This review discusses various microbial polymers, their mechanism of metal(loid) removal and their potential application in remediation of contaminated environment.
\end{abstract}

Keywords: biodegradation; biofilms; bioflocculant; biopolymers; biosurfactant; secondary metabolites; pollution

\section{Introduction}

Environmental pollution due to swift growth in chemical industries, battery production, electroplating and steel industries, fertilizer and pesticide production, and mining activities is one of the most important challenges that are of human health concern. Pollution caused by metal(loid)s poses a health risk to living organisms. The accumulation of metal(loid)s in the environment as a result of natural and anthropogenic activities has significantly altered the nature of the environment $[1,2]$. In the midst of diverse metal ions, cadmium, chromium, lead and mercury in wastewater and soil are hazardous to the environment and have been linked to certain ailments such as birth defects, damage of internal organs such as kidney and liver, certain learning disabilities, and a host of other diseases. Due to their carcinogenic, genotoxic, mutagenic or toxic effects, their presence in the environment poses health risks and harmful effects on living organisms [3-6].

Metal(loid)s are natural components of the earth's crust and are also produced from anthropogenic sources. Some metal(loid)s act as essential micro nutrients for living organisms, but at higher concentrations they can cause severe poisoning. Metal(loid) ions are non-degradable and thus persist in the ecosystem. They become bioavailable for removal as there is decrease in the surface tension of water at polluted sites [7].

Metal(loid) removal from contaminated environments usually involves three technologies namely: (1) Chemical, (2) physicochemical, and (3) biological techniques [2,7]. The techniques can overlap in some cases as a result of multidisciplinary research and paradigms shift in technology. However, there can be limitations to a particular technique as the operation condition might not be effective in a particular environment [2].

Conventional techniques for metal(loid) removal involves treatment of polluted soil with surfactants, organic and inorganic acids, water, reverse osmosis, adsorption processes, and metal(loid) chelating 
agents. However, these physicochemical techniques are expensive and do not guarantee effective removal of metal(loid) ions from the soil especially when metal(loid) concentrations are less than $100 \mathrm{mg} / \mathrm{L}$. Other disadvantages include non-specificity of the techniques for metal(loid) binding, high energy demand, land space requirements, and sometimes the methods are impracticable and often exchange one problem for the other $[4,8]$. Effective sequestration of metal(loid) from polluted environments demands a good metal(loid) complexing agent. Such a complexing agent must possess characteristics such as environmental stability, high solubility and good metal(loid) complexation potentials [4].

Bioremediation is a cost-effective alternative for metal(loid) decontamination of polluted environments. It offers a long term recovery and/or removal of metal(loid) ions from contaminated environments and can be used in combination with other techniques [2]. Various strategies have been developed by microbes for their continued existence in metal(loid) polluted environments. They adopt diverse detoxifying mechanisms that include bioaccumulation, biomineralization, biosorption and biotransformation for their survival [9] (Figure 1). These mechanisms are often triggered and activated when the concentration of metal(loid)s in their environment increases. They secrete many kinds of metal(loid)-binding metabolites, ranging from simple organic acids, alcohols to extracellular polymeric substances (EPS), slimes and sheaths, humic and fulvic acids, capsules, and biofilms which help in metal(loid) uptake from solution [10,11]. Metal sulfides and oxides are also trapped and absorbed by these extracellular polymers and proteins produced by microorganisms [11].

Microbial products have generated increasing attention lately due to their biodegradable nature, diversity, and low toxicity. This makes them superior to their chemical counterparts. These metabolites provide defensive mechanisms, increase metal(loid) bioavailability and facilitate reproductive processes $[12,13]$. The metabolic pathways of these microorganisms have been exploited for degradation and removal of pollutants in the environments. In contrast to organic pollutants, metal(loid) contamination presents a difficult challenge; metal(loid) ions are not biodegradable but can be converted to base metal(loid), complexed with an organic ligand, methylated, precipitated or volatilized. An approach to metal(loid) removal involves stable complex formation between metal(loid) ion and microbial polymers. This is as a consequence of the electrostatic interaction between metal(loid) ions and negatively charged microbial polymers [14].

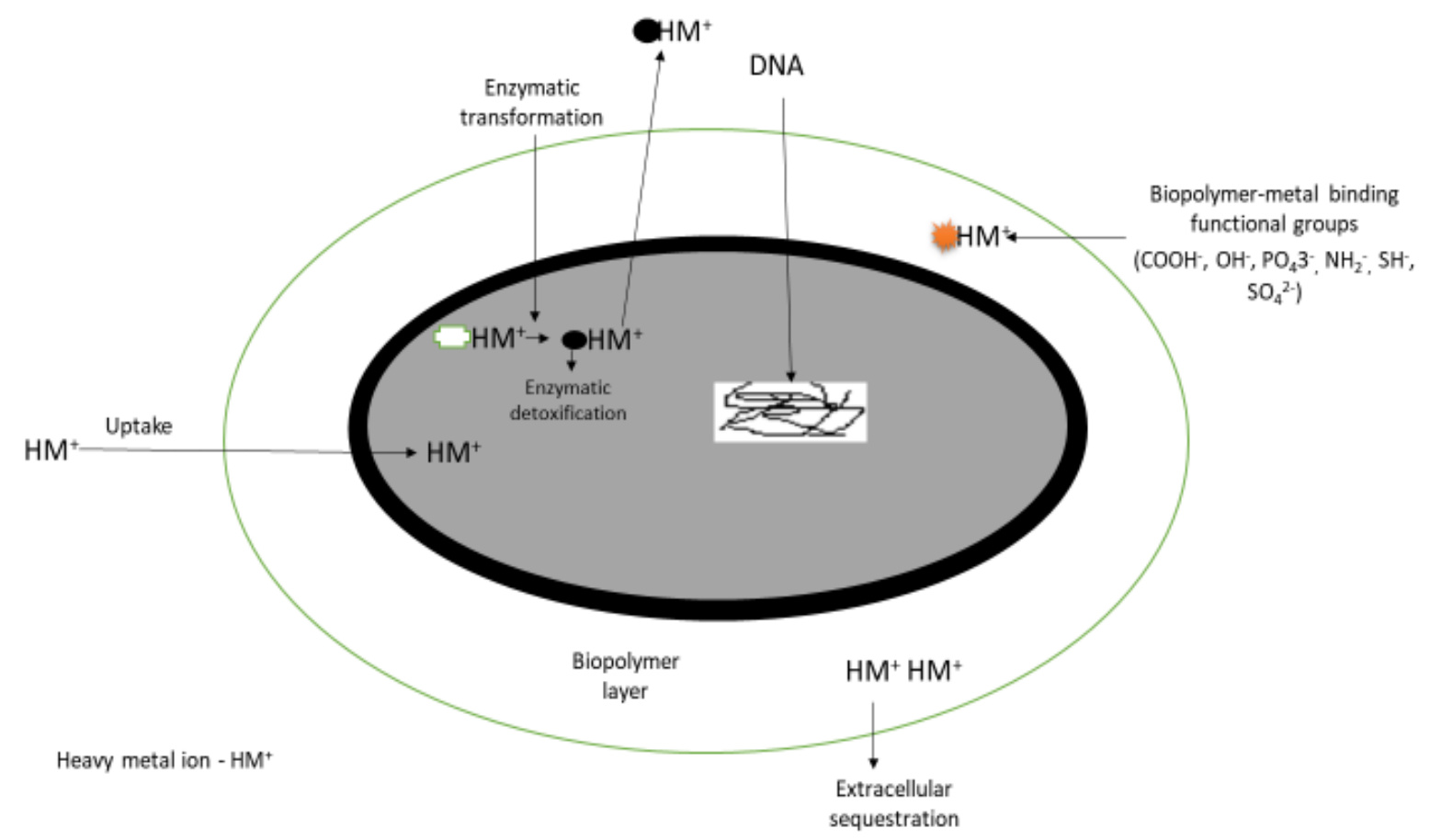

Figure 1. Mechanism of metal(loid) sequestration. 
From the beginning of cellular life, microorganisms are periodically exposed to metal(loid)s. This is evident in many of their enzymes that are composed of different essential divalent and transition metals at their active sites. These essential metal(loid)s are involved in maintaining protein structure and catalyzing key enzymatic reactions. They are thus needed in small quantity for cellular metabolism. The uptake of these metal(loid)s is regulated via the homeostatic mechanisms that ensure sufficient, but not excessive intake [12]. However, other metal(loid)s have no known biological function, but instead, they damage, inactivate or block enzymes functions because of their affinity for the sulfhydryl groups of proteins. Resistance to metal(loid)s most likely evolved shortly after life started, in an early metal(loid)-polluted world [12]. The synthesis of microbial polymers is driven by the need to survive in hostile environment and to assist in neutralization of toxic elements by sequestration [15].

Microbial processes that facilitate the detoxification and metal(loid) mobility using resistant microbial strains can be used for removal of metal(loid)s from soil, effluents and wastewaters. The use of microbial polymers is evolving as a promising technique to improve and enhance the effectiveness of metal(loid) removal. These compounds are often economic, versatile, environmentally friendly and can reduce the concentration and toxicity of pollutants.

In addition, these biopolymers have the capability to survive a wide range of temperature and $\mathrm{pH}$ and can affect interfaces. $\mathrm{pH}$ affects the functional groups involved in metal(loid) binding - therefore, providing varying binding sites on the surface of the organisms at different $\mathrm{pH}$ values. At high $\mathrm{pH}$, there are less $\mathrm{H}+$ to compete with metal(loid)s for binding sites on the biopolymers. At neutral $\mathrm{pH}$, they have functional groups that are negatively-charged and are capable of forming stable organo-metallic complexes with metal cations by means of diverse interactions [16]. A high temperature favors biopolymer-metal adsorption [17]. As the temperature increases, the affinity for the binding sites increases which favors direct contact between the biopolymer functional groups and metal ions [17]. However a very high temperature can cause structural damage of the biopolymer and some functional groups, which can reduce the efficiency of the polymer [16]. The metal binding ability of these biopolymers depends on the nature of biomass, specificity, affinity, $\mathrm{pH}$, temperature, hydrodynamics and functional groups present $[16,18]$.

The nature of the biopolymer varies depending on the origin, extraction procedure and adsorption characteristics [16]. Guibaud, et al. [19] made a comparison of the origin of some biopolymers. Their results showed that biopolymers from activated sludge have higher affinity for $\mathrm{Cd}^{2+}$ and $\mathrm{Pb}^{2+}$ than polymers from pure strains of bacteria. Polymers from anaerobic granular sludge were found to have lower affinity and proton exchange capability [20]. The functional groups present on these biopolymers also vary in their affinity for metal(loid) ions [16]. The carboxyl and the phosphate groups are the main functional groups that are involved in binding of metal ions and are effective at neutral $\mathrm{pH}$. Other functional groups include the amides, hydroxyl groups and nucleic acids [21]. These groups showed weaker binding ability compared to carboxyl and phosphate groups due to their high pKa values [22].

Microbial polymers are usually the first line of defense against metal(loid)s, and are important in protecting the interior of the microbial cell [16]. The use of isolated biopolymers is desired for easy availability in metal(loid) removal and circumvention of pathogenicity concerns of some producing organisms. This review article discusses the activities of useful microbial polymers in metal(loid)-binding, their mechanism of action and applications in bioremediation processes.

\section{Biosurfactant as a Metal(loid)-Complexing Biopolymer}

One of such microbial polymer is biosurfactant, which has been reported to be an effective metal(loid) complexing agent. They are surface-active metabolites with amphiphilic configuration. This amphiphilic metabolite has both hydrophilic and hydrophobic moieties, causing them to aggregate or form micelles at interfaces between fluids of different polarities, hence why it decreases interfacial surface tension between such fluids [23]. Typical hydrophilic groups of biosurfactants are amino acids, 
anions or cations, carbohydrates (mono-, di-, or polysaccharides) and peptides. The hydrophobic groups are the fatty acids which include branched, saturated, unsaturated, or hydroxylated fatty acids $[24,25]$.

Surfactants reduce the interfacial and surface tension, and increase the bioavailability, mobility, solubility and subsequent degradation of pollutants. There has been growing interest in this biopolymer due to several advantages it has over chemical surfactants. These characteristics include: (a) One or more chiral centers and functional groups; (b) complex structural diversity; (c) enhanced activity at extreme conditions of $\mathrm{pH}$, salinity and temperature; (d) excellent ability to form molecular assembly and liquid crystals; (e) gradual adsorption and continuing activity; (f) advanced surface activity and lower critical micelle concentration; $(\mathrm{g})$ superior biodegradability and lower toxicity; (h) versatile biological activity; and (i) production from renewable feedstocks [6,24,26-28].

Biosurfactants are extracted constituents of the bacterial or yeast cell membrane with structural variability. These secondary metabolites include high and low molecular-weight polymers that have the ability to effectively reduce interfacial and surface tension, and act as highly efficient emulsifiers. This stimulates the bioavailability of hydrophobic molecules by dissolving and emulsifying these hydrophobic compounds or by altering the cell's surface properties. Their production is considered as an important strategy to overcome pollutant-related stress by microorganisms [27]. They speed up the rate of mass transfer of hydrophobic compounds by making them readily available to microbes and thus acting as mediators. Furthermore, they induce changes in cell membrane properties which increases microbial adherence. This process is important when two immiscible fluids are present and direct substrate uptake is plausible [28]. Consequently, they help to surmount the diffusion-related mass transfer limitations [27].

Biosurfactants are produced by different microorganisms and have unique metal(loid)binding capacities and selectivity [29]. The selectivity in metal(loid)—binding is species specific [30] and important to remove target metal(loid) as other metal(loid)s in solution compete with the target metal(loid). The selectivity depends on the ionic radius and the stability of the surfactant-metal(loid) complex [31]. It has been shown that cadmium and lead have higher affinities for rhamnolipids from P. aeruginosa than any other soil components to which they are bound. Rhamnolipids have special affinity for non-essential and essential metallic cations, potentially leading to toxicity when in excess in exposure pathways, than with macronutrient cations [25,32].

Biosurfactants with anionic, cationic, or neutral charge are employed as washing agents. They can solubilize, disperse and desorb metal(loid)s from excavated sediments or soils in a washing unit [33]. Anionic biosurfactants have been proposed to bind metal(loid) ions by complexation or electrostatic techniques. These complexations result in an increase in the apparent metal(loid) solubility [34]. Therefore, the bioavailability of metal(loid)s is affected through their reduction by this biopolymer, which leads to the formation of less soluble metal salts including phosphate and sulfide precipitates [35]. By adsorbing onto the surface of sediments, biosurfactants form complexes with metal(loid) ions, and thus detaching metal(loid) ions from the sediment into the pore water. Therefore, they are able to remove metal(loid)s adsorbed to the sediment in association with surfactant micelles $[23,36]$.

Biosurfactants are produced by a variety of actinobacteria, bacteria and fungi with different classes. The classes include glycolipids, fatty acids, lipopeptides, lipoproteins, phospholipids, particulate and polymeric surfactants $[6,25]$. They have achieved significant importance with their activities and structural characteristics. Several bacterial genera such as Arthrobacter, Bacillus and Pseudomonas have been reported to produce surfactants with metal(loid) binding characteristics (Table 1).

\section{Mechanism of Biosurfactant Removal of Metal(loid)s}

Most microorganisms utilize the reductive pathway as an alternative to the oxidative pathway during transformation of metal(loid)s. This is due to the less toxic nature of the reduced form of metal(loid)s. The processes used include accumulation, complexation, efflux system and reduction mechanisms to tolerate metal(loid) exposure. Resistance to metal(loid) ions can also be conferred by 
gene clustering on plasmid when exposed to stress conditions [37]. Biosurfactants act as a link between the fluid interfaces, due to their amphiphilic nature and thus reduce the surface tension. Decrease in the surface tension of water increases mobilization of metal(loid) from unsaturated soils. Consequently, making removal of metal(loid)s possible.

Biosurfactants have been proposed to utilize two fundamental principles for metal(loid) removal from solution. Metal sorption mediated by biosurfactant is promoted through complexation of the free metal ion. This process employ's the Le Chatelier's principle and the solution phase activity of metal(loid) ion diminishes to promote desorption of metal(loid). Another mechanism is the direct contact with metal(loid) under reduced interfacial tension at solid-solution interface. This permits the biosurfactant to accumulate at solid-solution interface which aids metal(loid) binding [25,38].

Soils contaminated with metal(loid)s are treated by two basic techniques. The first technique involves metal(loid) immobilization on a strongly bound solid matrix to reduce migration. Nevertheless, the process does not permanently solve the problem as soil reuse is limited and also requires long-term monitoring. As a result, solidification is often limited to highly toxic or radioactive wastes. The other technique promotes mobility and migration of metal(loid) into liquid state by desorption and solubilization. This procedure offers a permanent solution to the pollution challenge. In addition, the treated soil can be recycled, which also improves further land-use alternative [39].

The mechanism of metal(loid) extraction by biosurfactant includes ion exchange, counter binding and precipitation. Ion exchange mechanism involves negatively charged anionic biosurfactants which bind with positively charged metal cations to form a bond that is stronger than the bond formed between metal ion and soil. The cell surface is conferred with a negative charge by biosurfactant. This process supports the electrostatic interaction with metal ion. The polar head moieties of surfactant micelles bind with the metal ions making them water soluble. The surfactant micelles then move the metal ions into solution, thus making it easier for metal recovery by flushing, washing, or pumping $[40,41]$. The metal(loid)-biosurfactant complex forms a strong bond that flushing with water removes the complex from soil matrix [41]. Cationic biosurfactants replace the same charged ions by competing with negatively charged surfaces [2,36]. The metal(loid) ion can then be recovered from the complex and used for different applications. The carboxyl group of the biosurfactant mono-rhamnolipid produced by $P$. aeruginosa has preference for metals such as $\mathrm{Cd}^{2+}, \mathrm{Pb}^{2+}$ and $\mathrm{Zn}^{2+}[36,42]$. The complex formed between metal and biosurfactant is non-toxic to bacteria. In the precipitation process, biosurfactants are added to soil during washing. As a result of the foaming characteristics of biosurfactants, the biosurfactant-metal complex can be removed from soil by the addition of air to cause foaming. The biosurfactant can then be recovered and recycled through precipitation by reducing the $\mathrm{pH}$ [41].

Surfactant concentration at which aggregation of ions or molecules (micelles) first begins to form is called the critical micelle concentration (CMC) where the surfactants assemble into an organized molecular arrangement [38]. Above the CMC, the surfactant molecules assemble together, forming aggregates and a range of micellar and vesicular configuration which depend on the $\mathrm{pH}$ of the solution [40]. The surfactants exist as single molecules or monomers at low concentration in aqueous solutions. The CMC depends on the composition and structure of the surfactant, temperature, ionic strength, and the presence and nature of organic compounds in the solutions. At the CMC of surfactant solutions, there is a radical change that occurs in many physico-chemical properties of the surfactant [43].

Biosurfactant is applied to contaminated soil for metal removal in a small quantity by using a cement mixer. The complex formed between the biopolymer and metal ion is then flushed out and the soil deposited back on site. Biosurfactant is then precipitated out of the complex formed leaving behind the metal ion. The bond formed by biosurfactant-metal ion is so strong that flushing with water eliminates the complex from soil matrix. Likewise, the process can be repeated for deep subsurface (in situ) contamination, but with increased flushing activities. Biosurfactant in cell free broth can be used directly or in dilute concentrations to polluted site. They are stable and effective in 
the production medium. Biosurfactant also enhance the degradation of organic contaminant in the presence of metal(loid)s by lowering the toxicity of metal(loid) ions and can be simultaneously used to eliminate metal(loid)s and organic pollutants [44].

Metal(loid)s form a strong bond with soil. Thus, making its bioavailability difficult for microbes. The activities of biosurfactant-metal(loid) ion complex in soil is influenced by soil's cation exchange capacity, soil composition and $\mathrm{pH}$, particle size, type and time of contamination, and geological pattern [25,38,45]. Long duration of metal(loid) contamination provides sufficient time for metal(loid) ion to stabilize and attach to soil, thus, making removal difficult $[25,38]$.

Decontamination tests have been performed on metal contaminated soil and sludge with different biosurfactants (Table 1). Studies have revealed the potential of lipopeptides, rhamnolipids, sophorolipids and surfactin in metal removal (Table 1). Dahrazma and Mulligan [33] examined the capability of rhamnolipids to remove metal ions from contaminated soil sediments. The rhamnolipid was able to remove up to $37 \%$ of $\mathrm{Cu}, 33 \%$ of $\mathrm{Ni}$, and $7.5 \%$ of $\mathrm{Zn}$ when applied in a continuous flow configuration. Rhamnolipid from Pseudomonas was shown to remove $19 \%$ of Fe and $52 \%$ of $\mathrm{Zn}$ in a cyclic treatment (Table 1).

Other biosurfactants that have been effective soil washing agents for metal(loid) removal include lipopeptide from Bacillus subtilis. This surfactant has been demonstrated to remove metals like $\mathrm{Cd}, \mathrm{Cu}$, $\mathrm{Co}, \mathrm{Pb}, \mathrm{Ni}$ and $\mathrm{Zn}$ from metal and hydrocarbon polluted soil [46]. The efficiency ranged from $26 \%$ for $\mathrm{Cu}$ to $44 \%$ for $\mathrm{Cd}$ (Table 1). Sophorolipids produced by Torulopsis bombicola have also been employed successfully in the removal of metal ions [47]. It has demonstrated the capacity to remove $60 \%$ of $\mathrm{Zn}$ and $25 \%$ of $\mathrm{Cu}$ in a soil sediment washing experiment (Table 1 ).

Table 1. Biosurfactant washing of some metal polluted environment.

\begin{tabular}{|c|c|c|c|c|c|c|c|}
\hline Organism & $\begin{array}{c}\text { Biosurfactant } \\
\text { Type }\end{array}$ & $\begin{array}{l}\text { Contaminated } \\
\text { Environment }\end{array}$ & $\mathrm{pH}$ & $\begin{array}{c}\text { Temperature } \\
\left({ }^{\circ} \mathrm{C}\right)\end{array}$ & Metals & $\begin{array}{l}\text { Efficiency } \\
(\%)\end{array}$ & Reference \\
\hline Bacillus subtilis A21 & $\begin{array}{l}\text { Lipopeptide } \\
(50 \times \mathrm{CMC})\end{array}$ & Soil & 9 & 25 & $\begin{array}{l}\mathrm{Cd}(989.8 \mathrm{mg} / \mathrm{kg}) \\
\mathrm{Co}(166.8 \mathrm{mg} / \mathrm{kg}) \\
\mathrm{Cu}(173.6 \mathrm{mg} / \mathrm{kg}) \\
\mathrm{Ni}(227.9 \mathrm{mg} / \mathrm{kg}) \\
\mathrm{Pb}(143.7 \mathrm{mg} / \mathrm{kg}) \\
\mathrm{Zn}(404.7 \mathrm{mg} / \mathrm{kg})\end{array}$ & $\begin{array}{c}44.2 \\
35.4 \\
26.2 \\
32.2 \\
40.3 \\
32.07 \\
\end{array}$ & [46] \\
\hline $\begin{array}{c}\text { Pseudomonas } \\
\text { aeruginosa CVCM } 411\end{array}$ & $\begin{array}{l}\text { Rhamnolipid } \\
(1 \mathrm{mg} / \mathrm{mL})\end{array}$ & Soil & 8 & 25 & $\begin{array}{l}\mathrm{Fe} \\
\mathrm{Zn}\end{array}$ & $\begin{array}{l}19 \\
52\end{array}$ & [49] \\
\hline Commercial & Rhamnolipid (5\%) & Soil & 6.5 & 25 & $\begin{array}{c}\mathrm{Cu}(140 \mathrm{mg} / \mathrm{kg}) \\
\mathrm{Ni}(76 \mathrm{mg} / \mathrm{kg}) \\
\mathrm{Zn}(4854 \mathrm{mg} / \mathrm{kg})\end{array}$ & $\begin{array}{c}37 \\
33.2 \\
7.5\end{array}$ & [33] \\
\hline Commercial & $\begin{array}{l}\text { Saponin } \\
\left(30 \mathrm{~g} / \mathrm{dm}^{3}\right)\end{array}$ & Sludge & 3 & 25 & $\begin{array}{l}\mathrm{Cr}(1000 \mathrm{ppm}) \\
\mathrm{Ni}(1000 \mathrm{ppm}) \\
\mathrm{Pb}(1360 \mathrm{ppm})\end{array}$ & $\begin{array}{l}56.1 \\
64.2 \\
73.2 \\
\end{array}$ & {$[50]$} \\
\hline $\begin{array}{l}\text { Candida sphaerica } \\
\text { UCP } 0995\end{array}$ & & Soil & & 27 & $\begin{array}{l}\mathrm{Fe}(1877 \mathrm{mg} / \mathrm{kg}) \\
\mathrm{Pb}(3038 \mathrm{mg} / \mathrm{kg}) \\
\mathrm{Zn}(1470 \mathrm{mg} / \mathrm{kg})\end{array}$ & $\begin{array}{l}95 \\
79 \\
90\end{array}$ & [1] \\
\hline Torulopsis bombicola & $\begin{array}{c}\text { Sophorolipid } \\
(4 \% \text { and } 0.7 \% \mathrm{HCl})\end{array}$ & Soil & 5.4 & - & $\begin{array}{l}\mathrm{Cu} \\
\mathrm{Zn}\end{array}$ & $\begin{array}{l}25 \\
60\end{array}$ & [47] \\
\hline $\begin{array}{l}\text { Candida lipolytica } \\
\text { UCP } 0988\end{array}$ & Lipoprotein & Soil & & & $\begin{array}{c}\mathrm{Cd}(0.9 \mathrm{mg} / \mathrm{kg}) \\
\mathrm{Cu}(13.3 \mathrm{mg} / \mathrm{kg}) \\
\mathrm{Fe}(52.5 \mathrm{~g} / \mathrm{kg}) \\
\mathrm{Pb}(14 \mathrm{mg} / \mathrm{kg}) \\
\mathrm{Zn}(19.1 \mathrm{mg} / \mathrm{kg})\end{array}$ & $\begin{array}{c}50 \\
96 \\
16.5 \\
15.4 \\
96\end{array}$ & [51] \\
\hline
\end{tabular}

Wang and Mulligan [52] used a commercially available rhamnolipid biosurfactant JBR425 produced by P. aeruginosa to remove arsenic and other metals (copper, lead and zinc) from mine tailings. They observed that $0.1 \%$ of the surfactant removed $148,74,2379$ and $259 \mathrm{mg} / \mathrm{kg}$ of As, Cu, 
$\mathrm{Pb}$ and $\mathrm{Zn}$ respectively under alkaline condition. They concluded that the mobilization of arsenic by the rhamnolipid surfactant is enhanced by the presence of other metal under alkaline condition. Consequently, allowing metal bridging through the formation of the biosurfactant-metal complex.

\section{Metal(loid) Removal by Microbial Flocculants}

Substances used in the separation of suspended solid-liquid are called flocculants [53]. Flocculation involves the floc formation through colloid aggregation. This is stimulated by a chemical substance called flocculant. There are three types of flocculating agents namely inorganic (alum, aluminum chloride and sulfate, ferrous sulfate, ferric chloride and polyaluminium chloride), natural (cellulose, chitosan, gum and mucilage, starch, tannin and microbial flocculant), and organic polymeric (polyacrylamide and polyethylene amine) flocculants [54-56]. Chemically synthesized flocculants possess inherent drawbacks of being toxic, cause serious health issues, produce large quantity of sludge, and are not readily degradable $[55,57,58]$. Therefore, bioflocculants gained increased attraction being environmental friendly, non-toxic, free of secondary pollution risk, and effective elimination of metal(loid)s and suspended solids from wastewaters [59].

Bioflocculants are polymers produced by bacteria during growth and contain complex mixtures of macromolecular polyelectrolytes produced by different organisms. They have various organic groups, such as aspartic and glutamic acid in the protein component, galacturonic and glucuronic acid in the polysaccharide constituent and uronic acids (containing a carbonyl and carboxylic acid component). These groups are responsible for metal binding [60]. The carboxyl groups on the molecular chain of this biopolymer allow the chain to stretch out due to electrostatic repulsion, and the extended molecular chains offer more effectual sites for attachment of particles. Metal form complexes with the carboxyl and amino functional groups of the bioflocculant by neutralizing and stabilizing the residual charge as the distance of binding is shortened [61].

The flocculating efficiency depends on the contact area between the adsorbate and bioflocculant, suspended particle size, concentration and structure of adsorbate, contact time, ionic strength, $\mathrm{pH}$, temperature and the type of producing organism [53]. The flocculant choice has a significant effect on the flocculation performance, strength of particle aggregation, and the strength and number of bonds formed due to flocculation [62].

\section{Mechanism of Metal(loid) Removal by Flocculation}

The formation of interface with metal(loid) ions was attributed to be the mechanism of metal(loid) removal by bioflocculant. The interface formation depends on ionic groups such as amino, carboxyl and hydroxyl groups in the biopolymer which enable metal-floc interactions $[63,64]$. It is a metabolic-independent process in which communication between metal ions and the flocculant functional groups can be established by complexation, immobilization, ion exchange, physical adsorption and precipitation processes [64].

Similarly, charge neutralization, electrostatic patch and polymer bridging are other mechanisms of flocculation. Metal ions are positively charged and most bioflocculants are negatively charged which makes charge neutralization applicable. The cation exchange ability makes the electrostatic forces between metal ions and bioflocculant possible [55]. During the process of charge neutralization, the surface charge density of the particle is reduced by bioflocculant adsorption and the particles sufficiently aggregate for the effectiveness of the attractive forces [65].

In a bridging mechanism, the bioflocculant serves as a bridge in the complex formed by particle-polymer-particle. Some functional groups of the biopolymer adsorb to the metal ions when the biopolymer comes in contact with the metal ion, thus, leaving the unabsorbed metal ions to extend out into the solution. The second biopolymer with unattached adsorption sites then comes in contact with the extended segments for attachment to occur. A metal-biopolymer-metal complex is thus formed with the biopolymer serving as a bridge [55]. Before flocculation could occur, the biopolymer must not only come in contact with the particles, it must also conquer the electrostatic repulsive forces between 
particles $[53,66]$. Efficient bridging mechanisms is attributed to the following characteristics: The ionic strength of the suspension, the molecular weight of the biopolymer, the net charge of the biopolymer, the suspended particles, and the nature kind of mixing [53].

The producing microorganisms determine the structural characteristics of the biopolymer produced. Metal(loid) ions demonstrate varying effect on different biopolymer. These effects depend on the concentration and valence and metal(loid) ions [53,67]. The metal(loid)-binding interactions is influenced by various factors such as bioflocculant dosage, physico-chemical characteristics of metal(loid) ions, initial metal(loid) concentration, ionic strength, charge density, appropriate positioning with the binding site, conformation of polymer with adsorbed ions and tertiary structure of floc $[56,60,63,68]$.

Several bioflocculants have been reported in literature with strong metal(loid) adsorption capability (Table 2). Many of them have been isolated from soil and wastewaters and have various metal(loid) biosorption capacity.

Table 2. Metal(loid) removal by bioflocculant produced by different bacterial species.

\begin{tabular}{|c|c|c|c|c|c|c|}
\hline Isolate & Source & $\begin{array}{c}\text { Flocculating } \\
\text { Efficiency }(\%)\end{array}$ & $\begin{array}{l}\text { Metal(loid)s } \\
\text { Removed }\end{array}$ & $\begin{array}{c}\text { Metal(loid) } \\
\text { Removal (\%) }\end{array}$ & $\mathrm{pH}$ & Reference \\
\hline $\begin{array}{l}\text { Pseudomonas } \\
\text { aeruginosa }\end{array}$ & & 62.25 & $\begin{array}{l}\mathrm{Cu}(20 \mathrm{mg} / \mathrm{L}) \\
\mathrm{Hg}(20 \mathrm{mg} / \mathrm{L}) \\
\mathrm{Pb}(40 \mathrm{mg} / \mathrm{L}) \\
\mathrm{Cd}(40 \mathrm{mg} / \mathrm{L}) \\
\mathrm{As}(60 \mathrm{mg} / \mathrm{L}) \\
\mathrm{Zn}(60 \mathrm{mg} / \mathrm{L})\end{array}$ & $\begin{array}{c}87.39 \\
89.09 \\
79.7 \\
79.73 \\
72.96 \\
80.59\end{array}$ & 7 & {$[68]$} \\
\hline $\begin{array}{l}\text { Rhodococcus } \\
\text { erythropolis }\end{array}$ & Swine wastewater & 44.7 & $\mathrm{Cu}(100 \mathrm{mg} / \mathrm{L})$ & 96.9 & 6 & [59] \\
\hline $\begin{array}{l}\text { Bacillus subtilis } \\
\text { WD } 90\end{array}$ & Activated sludge & 90.69 & $\begin{array}{l}\mathrm{Cd}(60 \mathrm{mg} / \mathrm{L}) \\
\mathrm{Ni}(10 \mathrm{mg} / \mathrm{L})\end{array}$ & $\begin{array}{l}90.9 \\
90.7\end{array}$ & 8 & \multirow{2}{*}{ [69] } \\
\hline $\begin{array}{l}\text { Pantoea } \\
\text { agglomerans }\end{array}$ & Activated sludge & 87.84 & $\begin{array}{l}\mathrm{Cd}(60 \mathrm{mg} / \mathrm{L}) \\
\mathrm{Ni}(10 \mathrm{mg} / \mathrm{L})\end{array}$ & $\begin{array}{l}84.2 \\
92.8\end{array}$ & 7 & \\
\hline Paenibacillus elgii & Soil & 87 & $\begin{array}{l}\mathrm{Al}(2 \mathrm{mM}) \\
\mathrm{Co}(2 \mathrm{mM}) \\
\mathrm{Cu}(2 \mathrm{mM}) \\
\mathrm{Pb}(2 \mathrm{mM})\end{array}$ & $\begin{array}{l}72 \\
49 \\
53 \\
60\end{array}$ & 7.2 & [70] \\
\hline Bacillus cereus & $\begin{array}{l}\text { Marine sponge } \\
\text { (Dendrilla nigra) }\end{array}$ & 94 & $\begin{array}{l}\mathrm{Cu}(1-3 \mathrm{mM}) \\
\mathrm{Hg}(1-3 \mathrm{mM}) \\
\mathrm{Zn}(1-3 \mathrm{mM})\end{array}$ & $\begin{array}{l}\text { Significant } \\
\text { reduction }\end{array}$ & 7 & [54] \\
\hline Bacillus firmus & Soil & & $\begin{array}{l}\mathrm{Cu}(1000 \mathrm{mg} / \mathrm{L}) \\
\mathrm{Pb}(1000 \mathrm{mg} / \mathrm{L}) \\
\mathrm{Zn}(1000 \mathrm{mg} / \mathrm{L})\end{array}$ & $\begin{array}{l}74.9 \\
98.3 \\
61.8\end{array}$ & $\begin{array}{c}4 \\
4.5 \\
6\end{array}$ & [71] \\
\hline $\begin{array}{l}\text { Rothia sp. } \\
\text { ZHT4-13 }\end{array}$ & $\begin{array}{l}\text { Ruditapes philippinarum } \\
\text { conglutination mud }\end{array}$ & 86.22 & $\begin{array}{c}\mathrm{Cr}(1 \mathrm{mg} / \mathrm{L}) \\
\mathrm{Ni}(20 \mathrm{mg} / \mathrm{L})\end{array}$ & $\begin{array}{l}69.3 \\
19.2\end{array}$ & 9 & [72] \\
\hline
\end{tabular}

\section{Biofilms and Metal(loid) Removal}

Bacteria exist in colonies in nature, accumulating at interfaces to form cell mass as seen in biofilms, mats, flocs and sludge. Singh, et al. [73], described biofilms as clusters of microbial cells attached to a surface. This usually occurs in moist environments where there is sufficient flow of nutrients. They can be formed by single or several species of organisms consisting of algae, bacteria, fungi and protozoa. Biofilm is a stable, highly structured ecosystem usually enclosed in a matrix adhering to a dormant or living surface [74]. Biofilms develop on different surfaces such as living tissues, soil and aquatic environment, medical devices, industrial or potable water piping system [75]. Microbial biofilms develop an increased preformed resistance to hard-surface disinfectants, antibiotics, extreme $\mathrm{pH}$ and oxygen levels, desiccation and metal(loid) ions [76]. 
Biofilm offers the advantage of availability of nutrient, persistence in different metabolic states, and communication and exchange of genetic materials. Biofilm-mediated removal of metal(loid)s is crucial as high concentration of metal(loid)s is detrimental to planktonic organisms. Planktonic communities usually have a problem when they come in contact with metal(loid)s because metal(loid) ions have unique chemistries, and function via varied biochemical routes of toxicity. Biofilm increases the tolerance of microorganisms to metal(loid)s and acidic environment, due to better adaptation and survival as they are protected within a matrix [77]. The macromolecules within the biofilm matrix exhibit properties such as electrostatic interactions, hydrogen bonding and London dispersion forces. The EPS plays an active role in metal(loid) sorption as many of them are anionic in nature [78]. The close proximity within the biofilm and the physiological interactions among the organisms enhance metal(loid) tolerance and removal [73].

Metal(loid) sorption sites on biofilm include cell membrane and cell wall, extracellular polymeric substances and cytoplasm. Extracellular polymers consist mainly of polysaccharides, proteins, uronic acids (D-galacturonic, D-glucuronic and mannuronic acids), humic acids, ketal-linked pyruvates, lipids, nucleic acids, ionizable functional groups, and cell fragments $[18,75,79]$. Removal of metal(loid) mediated by microbial biofilm offers an effective and innocuous alternative to sequestration by planktonic organisms. This is due to the better chance of adaptation that cells in biofilm offers and their subsequent survival in a protected matrix $[73,75]$. The mineralization processes is improved in biofilm mediated removal by maintaining optimum $\mathrm{pH}$ conditions, localized solute and redox potential [75]. Acquired traits through horizontal gene transfer processes from the high cell density in the biofilm community also enhance their resistance abilities to metal(loid) ions [74].

The factors that influenced biofilm EPS metal(loid) binding include the surrounding $\mathrm{pH}$, ionic strength, metal(loid) concentration, EPS composition, physical gel state, organic matter component, and biomass. Furthermore, the ratio of carbohydrate to protein in the EPS also plays a major role in metal(loid) removal from wastewaters and in monitoring the state of the biofilm. A higher $\mathrm{pH}$ results in metal(loid) chelation with maximum binding affinity between $\mathrm{pH} 8-8.2$, while a lower $\mathrm{pH}$ favors the release of meta(loid)l ions from a bound state [18,78]. At acidic $\mathrm{pH}$, the binding anions such as $\mathrm{COO}^{-}$ groups are not readily available, thus, a few metallic ions are bounded [80]. The encasing EPS protects microbial cells in biofilm from metal(loid) stress through metal(loid) ion binding or by preventing metal(loid) diffusion within the biofilm [18].

Colonization of microorganisms on metal(loid)s is mediated by biofilms which play crucial role in their attachment. Metal sulfide dissolution is proposed to take place in the EPS layer of biofilm, and the method of occurrence is based on two postulates. It is first presumed that the complex formed by metal ion and the EPS is decreased as a result of an electron tunneling effect. In addition, the glucuronic acid-metal ion complex is unstable, thus, permitting metal ions to move inside the EPS space. If the metal ions migrate near the outer membrane, they will be re-oxidized by the cell's enzymatic system and can then reenter the oxidation/reduction cycle [75].

Various microbial biofilms have sorb metals by varying activities. Pseudomonas aeruginosa biofilm was demonstrated to be more resistant to $\mathrm{Cu}, \mathrm{Pb}$ and $\mathrm{Zn}$ ions than the free planktonic cells in a rotating-disk biofilm reactor [81]. The EPS encasing the biofilm was found to protect against metal(loid) by binding metal(loid) ions and preventing metal(loid) ion diffusion into the biofilm. In like manner, $\mathrm{Au}, \mathrm{Fe}$ and La were demonstrated to bind to P. aeruginosa PAO1 biofilm in a more significant amount than the planktonic cells [82]. The binding of metals by the biofilm of P. aeruginosa led to an increase in the electron density of the cells' surfaces when observed with the transmission electron micrograph. The shift in the production of lipopolysaccharide in P. aeruginosa PAO1 biofilm could be responsible for metal(loid) resistance. This showed that the mode of growth (biofilm or planktonic) affects the extent to which cells bind and precipitate metal(loid) ions [82].

The planktonic and biofilm cells of Candida tropicalis were exposed to a diverse range of metal(loid) ions ( $\mathrm{Ag}, \mathrm{Al}, \mathrm{Au}, \mathrm{Cd}, \mathrm{Co}, \mathrm{Cr}, \mathrm{Cu}, \mathrm{Hg}, \mathrm{Mn}, \mathrm{Ni}, \mathrm{Pb}, \mathrm{Se}, \mathrm{Te}$ and $\mathrm{Zn}$ ) in a time-dependent experiment [83]. The biofilm of $C$. tropicalis was found to be highly resistant to metal(loid) toxicity and was also found 
to be 65 times tolerant than planktonic cells. The extracellular matrix of the biofilm was observed to be the contributing factor responsible for metal(loid) resistance. The EPS restricted the movement of metal(loid) ions into the biofilm of $C$. tropicalis. The densely packed cells formed by the biofilm, which later developed into dome-shaped microcolonies could also be responsible for the metal(loid) resistance observed in the study [83].

The negatively charged carboxyl, phosphoryl and sulfhydryl groups existing in the EPS of biofilm produced Escherichia coli PHL628 was suggested to be responsible for sorption of copper [84]. In addition, increased exopolysaccharide produced per cell within the biofilm and the tortuosity that possibly impede transport of $\mathrm{Cu}$ into biofilms were also reported to be responsible for $\mathrm{Cu}$ sorption. The study showed that $\mathrm{Cu}$ sorption by the biofilm is 6 times more than planktonic cells of E. coli PHL628.

Quintelas, et al. [79] investigated the removal of chromium by biofilm of Arthrobacter viscosus supported on granular activated carbon from wastewater. They observed a simultaneous increase in chromium uptake by A. viscosus biofilm in the presence of organic compounds (o-cresol, phenol and chlorophenol). The biofilm can be applied in wastewater removal of metal(loid)s.

Von Canstein, et al. [85] evaluated the diversity of species and the efficiency of mercury-reducing biofilm in a packed-bed reactor. They found that biofilms, composing of multi-species organisms, retained large quantity of mercury compared to mono-species biofilms in a changing environment. The diversity of the microbial species inhabiting the biofilm resulted in superior bioreactor performance in a rapidly changing environment, hence, efficient metal(loid) removal [85]. Environmental and metal(loid) stress related issues that affect planktonic organisms and monoculture biofilms were reduced using multi-species biofilms. Biofilms with multi-species offer a superior survival niche, and increase the metabolic abilities in the presence of metal(loid)s [25]. There has been growing interest in metal(loid) removal by biofilm and with genetic engineering. It could be manipulated and improved upon for efficient metal(loid) removal.

\section{Conclusions and Future Direction}

The exploration of the properties of microbial polymers for in situ bioremediation will enhance metal(loid) removal from contaminated environments as most experiments are still laboratory based. The metabolic properties of microorganisms can be exploited for this purpose since the polymers are specific, tolerant to extreme conditions and have low toxicity. Techniques to elucidate the mechanisms of action of these polymers are needed to further understand their role in metal(loid)-binding and metal(loid) decontamination. Molecular techniques that enable the construction and improvement of the production of these biopolymers with specific metal(loid)-binding characteristics from robust environmental strains hold future promise. This can be accomplished through alteration of metabolic pathways, and insertion of new genes and plasmids into the genome of robust organisms. The description and characterization of enzymes, genes, and proteins responsible for the synthesis and metal(loid)-binding mechanism of these biopolymers will also provide insight on the level of alteration needed under different environmental conditions.

Author Contributions: A.S.A. and O.O.B. contributed equally in data collection, drafting of the manuscript and its critical review; and have given approval of the version to be published.

Funding: This research was funded by The World Academy of Science (TWAS) and the National Research Foundation (NRF) of South Africa with grant numbers [UID: 99779 and 81192].

Acknowledgments: We acknowledge the financial support of The World Academy of Science (TWAS) and the National Research Foundation (NRF) of South Africa. "This work is based on the research supported by the National Research Foundation of South Africa. Any opinion, finding and conclusion or recommendation expressed in this material is that of the authors and the NRF does not accept any liability in this regard".

Conflicts of Interest: The authors declare no conflict of interest. 


\section{References}

1. Luna, J.M.; Rufino, R.D.; Sarubbo, L.A. Biosurfactant from candida sphaerica ucp0995 exhibiting heavy metal remediation properties. Process Saf. Environ Prot. 2016, 102, 558-566. [CrossRef]

2. Sarubbo, L.; Rocha, R., Jr.; Luna, J.; Rufino, R.; Santos, V.; Banat, I. Some aspects of heavy metals contamination remediation and role of biosurfactants. Chem. Ecol. 2015, 31, 707-723. [CrossRef]

3. Ayangbenro, A.S.; Babalola, O.O. A new strategy for heavy metal polluted environments: A review of microbial biosorbents. Int. J. Environ. Res. Public Health 2017, 14, 94. [CrossRef] [PubMed]

4. Das, P.; Mukherjee, S.; Sen, R. Biosurfactant of marine origin exhibiting heavy metal remediation properties. Bioresour. Technol. 2009, 100, 4887-4890. [CrossRef] [PubMed]

5. Fashola, M.; Ngole-Jeme, V.; Babalola, O. Heavy metal pollution from gold mines: Environmental effects and bacterial strategies for resistance. Int. J. Environ. Res. Public Health 2016, 13, 1047. [CrossRef] [PubMed]

6. Sriram, M.I.; Kalishwaralal, K.; Deepak, V.; Gracerosepat, R.; Srisakthi, K.; Gurunathan, S. Biofilm inhibition and antimicrobial action of lipopeptide biosurfactant produced by heavy metal tolerant strain bacillus cereus nk1. Colloids Surf. B Biointerfaces 2011, 85, 174-181. [CrossRef] [PubMed]

7. Hashim, M.; Mukhopadhyay, S.; Sahu, J.N.; Sengupta, B. Remediation technologies for heavy metal contaminated groundwater. J. Environ. Manag. 2011, 92, 2355-2388. [CrossRef] [PubMed]

8. Voica, D.M.; Bartha, L.; Banciu, H.L.; Oren, A. Heavy metal resistance in halophilic bacteria and archaea. FEMS Microbiol. Lett. 2016, 363, fnw146. [CrossRef] [PubMed]

9. Lin, C.C.; Lin, H.L. Remediation of soil contaminated with the heavy metal $\left(\mathrm{cd}^{2+}\right)$. J. Hazard. Mater. 2005, 122, 7-15. [CrossRef] [PubMed]

10. Fomina, M.; Gadd, G.M. Biosorption: Current perspectives on concept, definition and application. Bioresour. Technol. 2014, 160, 3-14. [CrossRef] [PubMed]

11. Wu, G.; Kang, H.; Zhang, X.; Shao, H.; Chu, L.; Ruan, C. A critical review on the bio-removal of hazardous heavy metals from contaminated soils: Issues, progress, eco-environmental concerns and opportunities. J. Hazard. Mater. 2010, 174, 1-8. [CrossRef] [PubMed]

12. Valls, M.; De Lorenzo, V. Exploiting the genetic and biochemical capacities of bacteria for the remediation of heavy metal pollution. FEMS Microbiol. Rev. 2002, 26, 327-338. [CrossRef] [PubMed]

13. Vaishnav, P.; Demain, A.L. Unexpected applications of secondary metabolites. Biotechnol. Adv. 2011, 29, 223-229. [CrossRef] [PubMed]

14. Gutnick, D.; Bach, H. Engineering bacterial biopolymers for the biosorption of heavy metals; new products and novel formulations. Appl. Microbiol. Biotechnol. 2000, 54, 451-460. [CrossRef] [PubMed]

15. Van Hamme, J.D.; Singh, A.; Ward, O.P. Physiological aspects: Part 1 in a series of papers devoted to surfactants in microbiology and biotechnology. Biotechnol. Adv. 2006, 24, 604-620. [CrossRef] [PubMed]

16. Li, W.-W.; Yu, H.-Q. Insight into the roles of microbial extracellular polymer substances in metal biosorption. Bioresour. Technol. 2014, 160, 15-23. [CrossRef] [PubMed]

17. Kiran, B.; Kaushik, A. Chromium binding capacity of lyngbya putealis exopolysaccharides. Biochem. Eng. J. 2008, 38, 47-54. [CrossRef]

18. Pal, A.; Paul, A. Microbial extracellular polymeric substances: Central elements in heavy metal bioremediation. Indian J. Microbiol. 2008, 48, 49. [CrossRef] [PubMed]

19. Guibaud, G.; van Hullebusch, E.; Bordas, F.; d'Abzac, P.; Joussein, E. Sorption of cd (ii) and pb (ii) by exopolymeric substances (eps) extracted from activated sludges and pure bacterial strains: Modeling of the metal/ligand ratio effect and role of the mineral fraction. Bioresour. Technol. 2009, 100, 2959-2968. [CrossRef] [PubMed]

20. Guibaud, G.; Bhatia, D.; d'Abzac, P.; Bourven, I.; Bordas, F.; Van Hullebusch, E.D.; Lens, P.N. Cd (ii) and $\mathrm{pb}$ (ii) sorption by extracellular polymeric substances (eps) extracted from anaerobic granular biofilms: Evidence of a ph sorption-edge. J. Taiwan Inst. Chem. Eng. 2012, 43, 444-449. [CrossRef]

21. Zhang, D.; Pan, X.; Mostofa, K.M.; Chen, X.; Mu, G.; Wu, F.; Liu, J.; Song, W.; Yang, J.; Liu, Y. Complexation between hg (ii) and biofilm extracellular polymeric substances: An application of fluorescence spectroscopy. J. Hazard. Mater. 2010, 175, 359-365. [CrossRef] [PubMed]

22. Guibaud, G.; Tixier, N.; Bouju, A.; Baudu, M. Relation between extracellular polymers' composition and its ability to complex cd, cu and pb. Chemosphere 2003, 52, 1701-1710. [CrossRef] 
23. Mazaheri, A.M.; Tabatabaee, M. Biosurfactants and their use in upgrading petroleum vacuum distillation residue: A review. Int. J. Environ. Res. 2010, 4, 549-572.

24. Kitamoto, D.; Morita, T.; Fukuoka, T.; Konishi, M.-A.; Imura, T. Self-assembling properties of glycolipid biosurfactants and their potential applications. Curr. Opin. Colloid Interface Sci. 2009, 14, 315-328. [CrossRef]

25. Singh, P.; Cameotra, S.S. Enhancement of metal bioremediation by use of microbial surfactants. Biochem. Biophys. Res. Commun. 2004, 319, 291-297. [CrossRef] [PubMed]

26. Henkel, M.; Geissler, M.; Weggenmann, F.; Hausmann, R. Production of microbial biosurfactants: Status quo of rhamnolipid and surfactin towards large-scale production. Biotechnol. J. 2017, 12, 1600561. [CrossRef] [PubMed]

27. Bezza, F.A.; Chirwa, E.M.N. Biosurfactant-enhanced bioremediation of aged polycyclic aromatic hydrocarbons (pahs) in creosote contaminated soil. Chemosphere 2016, 144, 635-644. [CrossRef] [PubMed]

28. Dadrasnia, A.; Ismail, S. Biosurfactant production by bacillus salmalaya for lubricating oil solubilization and biodegradation. Int. J. Environ. Res. Public Health 2015, 12, 9848-9863. [CrossRef] [PubMed]

29. Arjoon, A.; Olaniran, A.; Pillay, B. Co-contamination of water with chlorinated hydrocarbons and heavy metals: Challenges and current bioremediation strategies. Int. J. Environ. Sci. Technol. 2013, 10, 395-412. [CrossRef]

30. Miller, R.M. Biosurfactant-facilitated remediation of metal-contaminated soils. Environ. Health Perspect. 1995, 103, 59. [CrossRef] [PubMed]

31. Yuan, X.; Meng, Y.; Zeng, G.; Fang, Y.; Shi, J. Evaluation of tea-derived biosurfactant on removing heavy metal ions from dilute wastewater by ion flotation. Colloids Surf. A: Physicochem. Eng. Asp. 2008, 317, $256-261$. [CrossRef]

32. Torrens, J.L.; Herman, D.C.; Miller-Maier, R.M. Biosurfactant (rhamnolipid) sorption and the impact on rhamnolipid-facilitated removal of cadmium from various soils under saturated flow conditions. Environ. Sci. Technol. 1998, 32, 776-781. [CrossRef]

33. Dahrazma, B.; Mulligan, C.N. Investigation of the removal of heavy metals from sediments using rhamnolipid in a continuous flow configuration. Chemosphere 2007, 69, 705-711. [CrossRef] [PubMed]

34. Rufino, R.D.; Luna, J.M.; Campos-Takaki, G.M.; Ferreira, S.R.; Sarubbo, L.A. Application of the biosurfactant produced by candida lipolytica in the remediation of heavy metals. Chem. Eng. 2012, 27. [CrossRef]

35. Mosa, K.A.; Saadoun, I.; Kumar, K.; Helmy, M.; Dhankher, O.P. Potential biotechnological strategies for the cleanup of heavy metals and metalloids. Front. Plant Sci. 2016, 7, 1-14. [CrossRef] [PubMed]

36. Franzetti, A.; Gandolfi, I.; Fracchia, L.; Van Hamme, J.; Gkorezis, P.; Marchant, R.; Banat, I.M. Biosurfactant use in heavy metal removal from industrial effluents and contaminated sites. In Biosurfactants: Production and Utilization-Processes, Technologies, and Economics; Kosaric, N.F.V.S., Ed.; CRC Press: Boca Raton, FL, USA, 2014; Volume 159, pp. 361-369.

37. Gnanamani, A.; Kavitha, V.; Radhakrishnan, N.; Rajakumar, G.S.; Sekaran, G.; Mandal, A. Microbial products (biosurfactant and extracellular chromate reductase) of marine microorganism are the potential agents reduce the oxidative stress induced by toxic heavy metals. Colloids Surf. B Biointerfaces 2010, 79, 334-339. [CrossRef] [PubMed]

38. Chakraborty, J.; Das, S. Biosurfactant-based bioremediation of toxic metals. Microb. Biodegrad. Bioremediat. 2014, 167-201. [CrossRef]

39. Hong, K.-J.; Tokunaga, S.; Kajiuchi, T. Evaluation of remediation process with plant-derived biosurfactant for recovery of heavy metals from contaminated soils. Chemosphere 2002, 49, 379-387. [CrossRef]

40. Aşçı, Y.; Nurbaş, M.; Açıkel, Y.S. Investigation of sorption/desorption equilibria of heavy metal ions on/from quartz using rhamnolipid biosurfactant. J. Environ. Manag. 2010, 91, 724-731. [CrossRef] [PubMed]

41. Mulligan, C.N. Environmental applications for biosurfactants. Environ. Pollut. 2005, 133, 183-198. [CrossRef] [PubMed]

42. Juwarkar, A.A.; Nair, A.; Dubey, K.V.; Singh, S.; Devotta, S. Biosurfactant technology for remediation of cadmium and lead contaminated soils. Chemosphere 2007, 68, 1996-2002. [CrossRef] [PubMed]

43. Bustamante, M.; Duran, N.; Diez, M. Biosurfactants are useful tools for the bioremediation of contaminated soil: A review. J. Soil Sci. Plant Nutr. 2012, 12, 667-687. [CrossRef]

44. Pacwa-Płociniczak, M.; Płaza, G.A.; Piotrowska-Seget, Z.; Cameotra, S.S. Environmental applications of biosurfactants: Recent advances. Int. J. Mol. Sci. 2011, 12, 633-654. [CrossRef] [PubMed] 
45. Marchant, R.; Banat, I.M. Biosurfactants: A sustainable replacement for chemical surfactants? Biotechnol. Lett. 2012, 34, 1597-1605. [CrossRef] [PubMed]

46. Singh, A.K.; Cameotra, S.S. Efficiency of lipopeptide biosurfactants in removal of petroleum hydrocarbons and heavy metals from contaminated soil. Environ. Sci. Pollut. Res. 2013, 20,7367-7376. [CrossRef] [PubMed]

47. Mulligan, C.N.; Yong, R.N.; Gibbs, B.F. Heavy metal removal from sediments by biosurfactants. J. Hazard. Mater. 2001, 85, 111-125. [CrossRef]

48. Mulligan, C.N.; Yong, R.N.; Gibbs, B.F. Removal of heavy metals from contaminated soil and sediments using the biosurfactant surfactin. J. Soil Contam. 1999, 8, 231-254. [CrossRef]

49. Diaz, M.A.; De Ranson, I.U.; Dorta, B.; Banat, I.M.; Blazquez, M.L.; Gonzalez, F.; Muñoz, J.A.; Ballester, A. Metal removal from contaminated soils through bioleaching with oxidizing bacteria and rhamnolipid biosurfactants. Soil Sedim. Contam. Int. J. 2015, 24, 16-29. [CrossRef]

50. Gao, L.; Kano, N.; Sato, Y.; Li, C.; Zhang, S.; Imaizumi, H. Behavior and distribution of heavy metals including rare earth elements, thorium, and uranium in sludge from industry water treatment plant and recovery method of metals by biosurfactants application. Bioinorg. Chem. Appl. 2012, 2012. [CrossRef] [PubMed]

51. Rufino, R.; Rodrigues, G.; Campos-Takaki, G.; Sarubbo, L.; Ferreira, S. Application of a yeast biosurfactant in the removal of heavy metals and hydrophobic contaminant in a soil used as slurry barrier. Appl. Environ. Soil Sci. 2011, 2011. [CrossRef]

52. Wang, S.; Mulligan, C.N. Rhamnolipid biosurfactant-enhanced soil flushing for the removal of arsenic and heavy metals from mine tailings. Process Biochem. 2009, 44, 296-301. [CrossRef]

53. Okaiyeto, K.; Nwodo, U.U.; Okoli, S.A.; Mabinya, L.V.; Okoh, A.I. Implications for public health demands alternatives to inorganic and synthetic flocculants: Bioflocculants as important candidates. MicrobiologyOpen 2016, 5, 177-211. [CrossRef] [PubMed]

54. Sajayan, A.; Seghal Kiran, G.; Priyadharshini, S.; Poulose, N.; Selvin, J. Revealing the ability of a novel polysaccharide bioflocculant in bioremediation of heavy metals sensed in a vibrio bioluminescence reporter assay. Environ. Pollut. 2017, 228, 118-127. [CrossRef] [PubMed]

55. Lee, C.S.; Chong, M.F.; Robinson, J.; Binner, E. A review on development and application of plant-based bioflocculants and grafted bioflocculants. Ind. Eng. Chem. Res. 2014, 53, 18357-18369. [CrossRef]

56. Salehizadeh, H.; Yan, N. Recent advances in extracellular biopolymer flocculants. Biotechnol. Adv. 2014, 32, 1506-1522. [CrossRef] [PubMed]

57. Zhai, L.-F.; Sun, M.; Song, W.; Wang, G. An integrated approach to optimize the conditioning chemicals for enhanced sludge conditioning in a pilot-scale sludge dewatering process. Bioresour. Technol. 2012, 121, 161-168. [CrossRef] [PubMed]

58. Farag, S.; Zaki, S.; Elkady, M.; Abd-El-Haleem, D. Production and characteristics of a bioflocculant produced by pseudomonas sp. Strain 38a. J. Adv. Biolo. 2014, 4, 286-295.

59. Guo, J. Characteristics and mechanisms of $\mathrm{cu}$ (ii) sorption from aqueous solution by using bioflocculant mbfr10543. Appl. Microbiol. Biotechnol. 2015, 99, 229-240. [CrossRef] [PubMed]

60. Lin, J.; Harichund, C. Isolation and characterization of heavy metal removing bacterial bioflocculants. Afr. J. Microbiol. Res. 2011, 5, 599-607.

61. Pathak, M.; Devi, A.; Sarma, H.K.; Lal, B. Application of bioflocculating property of pseudomonas aeruginosa strain iasst201 in treatment of oil-field formation water. J. Basic Microbiol. 2014, 54, 658-669. [CrossRef] [PubMed]

62. Zhang, Z.; Wu, C.; Wu, Y.; Hu, C. Comparison of coagulation performance and floc properties of a novel zirconium-glycine complex coagulant with traditional coagulants. Environ. Sci. Pollut. Res. 2014, 21, 6632-6639. [CrossRef] [PubMed]

63. Deng, S.; Yu, G.; Ting, Y.P. Production of a bioflocculant by aspergillus parasiticus and its application in dye removal. Colloids Surf. B Biointerfaces 2005, 44, 179-186. [CrossRef] [PubMed]

64. Sathiyanarayanan, G.; Bhatia, S.K.; Kim, H.J.; Kim, J.-H.; Jeon, J.-M.; Kim, Y.-G.; Park, S.-H.; Lee, S.H.; Lee, Y.K.; Yang, Y.-H. Metal removal and reduction potential of an exopolysaccharide produced by arctic psychrotrophic bacterium pseudomonas sp. Pamc 28620. RSC Adv. 2016, 6, 96870-96881. [CrossRef]

65. Salehizadeh, H.; Shojaosadati, S.A. Extracellular biopolymeric flocculants: Recent trends and biotechnological importance. Biotechnology Advances 2001, 19, 371-385. [CrossRef] 
66. Wang, L.; Ma, F.; Qu, Y.; Sun, D.; Li, A.; Guo, J.; Yu, B. Characterization of a compound bioflocculant produced by mixed culture of rhizobium radiobacter $\mathrm{f} 2$ and bacillus sphaeicus $\mathrm{f} 6$. World J. Microbiol. Biotechnol. 2011, 27, 2559-2565. [CrossRef]

67. Wu, J.Y.; Ye, H.F. Characterization and flocculating properties of an extracellular biopolymer produced from a bacillus subtilis dyu1 isolate. Process Biochem. 2007, 42, 1114-1123. [CrossRef]

68. Gomaa, E.Z. Production and characteristics of a heavy metals removing bioflocculant produced by pseudomonas aeruginosa. Polish J. Microbiol. 2012, 61, 281-289.

69. Kaewchai, S.; Prasertsan, P. Biosorption of heavy metal by thermotolerant polymer-producing bacterial cells and the bioflocculant. Songklanakarin J. Sci. Technol. 2002, 24, 421-430.

70. Li, O.; Lu, C.; Liu, A.; Zhu, L.; Wang, P.-M.; Qian, C.-D.; Jiang, X.-H.; Wu, X.-C. Optimization and characterization of polysaccharide-based bioflocculant produced by paenibacillus elgii b69 and its application in wastewater treatment. Bioresour. Technol. 2013, 134, 87-93. [CrossRef] [PubMed]

71. Salehizadeh, H.; Shojaosadati, S.A. Removal of metal ions from aqueous solution by polysaccharide produced from bacillus firmus. Water Res. 2003, 37, 4231-4235. [CrossRef]

72. Gao, Q.; Zhu, X.-H.; Mu, J.; Zhang, Y.; Dong, X.-W. Using ruditapes philippinarum conglutination mud to produce bioflocculant and its applications in wastewater treatment. Bioresour. Technol. 2009, 100, 4996-5001. [CrossRef] [PubMed]

73. Singh, R.; Paul, D.; Jain, R.K. Biofilms: Implications in bioremediation. Trends Microbiol. 2006, 14, $389-397$. [CrossRef] [PubMed]

74. Farasin, J.; Koechler, S.; Varet, H.; Deschamps, J.; Dillies, M.A.; Proux, C.; Erhardt, M.; Huber, A.; Jagla, B.; Briandet, R. Comparison of biofilm formation and motility processes in arsenic-resistant thiomonas spp. Strains revealed divergent response to arsenite. Microb. Biotechnol. 2017, 10, 789-803. [CrossRef] [PubMed]

75. Vu, B.; Chen, M.; Crawford, R.J.; Ivanova, E.P. Bacterial extracellular polysaccharides involved in biofilm formation. Molecules 2009, 14, 2535-2554. [CrossRef] [PubMed]

76. Morel, M.A.; Ubalde, M.C.; Olivera-Bravo, S.; Callejas, C.; Gill, P.R.; Castro-Sowinski, S. Cellular and biochemical response to $\mathrm{cr}$ (vi) in stenotrophomonas sp. FEMS Microbiol. Lett. 2009, 291, 162-168. [CrossRef] [PubMed]

77. Edwards, S.J.; Kjellerup, B.V. Applications of biofilms in bioremediation and biotransformation of persistent organic pollutants, pharmaceuticals/personal care products, and heavy metals. Appl. Microbiol. Biotechnol. 2013, 97, 9909-9921. [CrossRef] [PubMed]

78. van Hullebusch, E.D.; Zandvoort, M.H.; Lens, P.N. Metal immobilisation by biofilms: Mechanisms and analytical tools. Rev. Environ. Sci. Biotechnol. 2003, 2, 9-33. [CrossRef]

79. Quintelas, C.; Sousa, E.; Silva, F.; Neto, S.; Tavares, T. Competitive biosorption of ortho-cresol, phenol, chlorophenol and chromium (vi) from aqueous solution by a bacterial biofilm supported on granular activated carbon. Process Biochem. 2006, 41, 2087-2091. [CrossRef]

80. Dominguez-Benetton, X.; Varia, J.C.; Pozo, G.; Modin, O.; ter-Heijne, A.; Fransaer, J.; Rabaey, K. Metal recovery by microbial electro-metallurgy. Prog. Mater. Sci. 2018, 94, 435-461. [CrossRef]

81. Teitzel, G.M.; Parsek, M.R. Heavy metal resistance of biofilm and planktonic pseudomonas aeruginosa. Appl. Environ. Microbiol. 2003, 69, 2313-2320. [CrossRef] [PubMed]

82. Langley, S.; Beveridge, T. Metal binding by pseudomonas aeruginosa pao1 is influenced by growth of the cells as a biofilm. Can. J. Microbiol. 1999, 45, 616-622. [CrossRef] [PubMed]

83. Harrison, J.J.; Rabiei, M.; Turner, R.J.; Badry, E.A.; Sproule, K.M.; Ceri, H. Metal resistance in candida biofilms. FEMS Microbiol. Ecol. 2006, 55, 479-491. [CrossRef] [PubMed]

84. Hu, Z.; Jin, J.; Abruña, H.D.; Houston, P.L.; Hay, A.G.; Ghiorse, W.C.; Shuler, M.L.; Hidalgo, G.; Lion, L.W. Spatial distributions of copper in microbial biofilms by scanning electrochemical microscopy. Environ. Sci. Technol. 2007, 41, 936-941. [CrossRef] [PubMed]

85. Von Canstein, H.; Kelly, S.; Li, Y.; Wagner-Döbler, I. Species diversity improves the efficiency of mercury-reducing biofilms under changing environmental conditions. Appl. Environ. Microbiol. 2002, 68, 2829-2837. [CrossRef] [PubMed]

(C) 2018 by the authors. Licensee MDPI, Basel, Switzerland. This article is an open access article distributed under the terms and conditions of the Creative Commons Attribution (CC BY) license (http:/ / creativecommons.org/licenses/by/4.0/). 